\title{
Proceeding
}

Supplementary Issue: Winter Conferences of Sports Science. Costa Blanca Sports Science Events, 22-23 March 2021. Alicante, Spain.

\section{Civic patriotism among young sportsman in the South of Russia: Sociological analysis and diagnostics}

\author{
YURIY G. VOLKOV $\triangle$, ELENA YU KOLESNIKOVA, YAKOV A. ASLANOV, VICTORIYA O. VAGINA \\ Institute of Sociology and Regional Studies, Southern Federal University, Rostov-on-Don, Russian \\ Federation
}

\begin{abstract}
Purpose: This article is aimed at revealing the specifics of civil and Patriotic practices in the youth environment of the South Russian region. Methodology: The sociological study used methods of qualitative operational analysis and theoretical interpretation of the obtained empirical data, as well as methods of sociological diagnostics aimed at the conceptual generalization of the results of empirical research by social recognition of the qualitative characteristics of civil patriotism in the youth environment as an integral social phenomenon. Result: In modern Russian society, patriotism is positively perceived by the majority, including young Russians, who associate it with love for the Motherland and a willingness to stand up for it. However, state patriotism in the youth environment lacks citizenship, that is, the desire of young people to actively participate in social Affairs, working for the benefit of society and the social environment. Applications: This research can be used for the universities, teachers and students. Novelty/Originality: The sociological analysis and diagnostics reveal the reasons for the low level of civic patriotism among young people, as well as the factors that hinder its development in regional communities in the South of Russia.

Keywords: Young sportsman; Patriotism; Imitation patriotism; State patriotism; Civic patriotism; Civic patriotic consciousness; Civic patriotic practices.

Cite this article as:

Volkov, Y.G., Kolesnikova, E. Y., Aslanov, Y.A., \& Vagina, V.O. (2021). Civic patriotism among young sportsman in the South of Russia: Sociological analysis and diagnostics. Journal of Human Sport and Exercise, 16(3proc), S1244-S1252. https://doi.org/10.14198/ihse.2021.16.Proc3.40
\end{abstract}

Corresponding author. Institute of Sociology and Regional Studies, Southern Federal University, Rostov-on-Don, Russian Federation.

E-mail: ugvolkov@sfedu.ru

Abstract submitted to: Winter Conferences of Sports Science. Costa Blanca Sports Science Events, 22-23 March 2021. Alicante, Spain.

JOURNAL OF HUMAN SPORT \& EXERCISE ISSN 1988-5202.

(c) Faculty of Education. University of Alicante.

doi:10.14198/jhse.2021.16.Proc3.40 


\section{INTRODUCTION}

Patriotism has recently been suggested for Russian society as a national idea and unifying principle well perceived by the majority, including in regional communities in the South of Russia. According to the results of sociological studies, $86 \%$ of young Russians consider patriotism as one of the most important human qualities related to love for the motherland (Gorshkov, 2016). However, Russian patriotism, which causes a set of positive feelings in Russians (Mukhametzyanova et al., 2018), still lacks, as some researchers note, citizenship, that is, the desire to change the system, ensuring a decent future for the country (Minakhmetova et al., 2017; Volkov et al., 2018; Oborsky et al., 2018; Makarova et al., 2019).

Young Russians, seeing the essence of patriotism in love for the motherland, mostly do not associate it with the need to display an active civil position. Therefore, young people in regional communities in the South of Russia, calling themselves patriots, do not particularly seek in practice to actively participate in the affairs of society, to be useful to society, to contribute to the development of the country, to be responsible for their deeds (Patriotism, citizenship and solidarity in regional communities in the South of Russia: a collective monograph, 2018). A characteristic feature of such patriotism is its publicity, which contains, on the one hand, the risks of turning patriotism in the youth environment into a fashion trend, associated with the imitation of a socially approved way of thinking rather than with the expression of the actual intentions of young people. On the other hand, patriotism, based only on love for the motherland, contains the risks of nationalism (Cohen and Nussbaum, 1996; Viroli, 1997), as evidenced by the growth of nationalist sentiments among the youth (Puzanova and Larina, 2017). However, it should be stressed that in general, the number of Russians sympathetic to the national patriotic ideology, currently does not exceed 6-7\% (Gorshkov, 2016).

It should, however, be noted that if earlier patriotism of youth was of mainly military-patriotic character and more connected with negative mobilization (to fight the enemy), than positive (to build the country), now the military-patriotic component of patriotism gives way to a creative one, focused on success and achievements (Semenov, 2017). The results of sociological studies prove that in regional communities in the South of Russia there is a growing number of young people who associate patriotism with the desire to be useful to society (Baibarin, Mashkin and Shelengovskiy, 2016; Faleeva et al., 2017; Cherdymova et al., 2018; Gorbunov et al., 2019), to actively participate in the affairs of the society and the state, to protect interests, rights and freedoms of citizens in solidarity. Besides, being patriots, these young people, engaged in various youth groups, are more capable of critical statements and protest actions than other Russians (Cornilov et al., 2019). All this indicates that a special group of civic patriotism is being formed in the youth environment in Russian society, whose representatives not only love their Homeland and are proud of their country, but also strive to make it better. In this regard, the sociological analysis and diagnosis of civic patriotism among youth in the South of Russia acquires special scientific and practical importance.

\section{Literature review}

The scientific literature has already considered various aspects related to the study of patriotism and citizenship, patriotic and civic practices in regional communities in the South of Russia (Patriotism, citizenship and solidarity in regional communities in the South of Russia: a collective monograph, 2018: 86, 197; Lubsky et al., 2018; Volkov et al., 2018; Koichuev, 2011). At the same time, the researchers draw attention to the fact that in the patriotic consciousness of the population patriotic attitudes are still poorly correlated with civic values, ultimately making it difficult to develop civic patriotism in regional communities (Vereshchagina, 2018; Podymov et al., 2019; Nguyen et al., 2020a). In this regard, the scientific literature raises an issue of possible ways to overcome the shortage of citizenship in Russian patriotism and the prospects for the development of civil patriotism in Russian society (Lubsky, 2017; Lubsky, 2019). 
Emphasizing the high level of patriotism in regional communities, regardless of the ethnicity of their population, the authors note that the level of patriotism among the youth is lower than among the older generation (Shakhbanova, 2017). However, the level of civic patriotism among young people is higher than among representatives of other social groups. Thus, identifying various groups of civic patriotism in the South of Russia, the researchers point out that as the "resource base" for the formation and development of civic patriotism in the Southern Russian regions primarily serves the youth as a carrier of patriotic attitudes and civic values, related to the critical perception of social reality and civic activity (Patriotism, citizenship and solidarity in regional communities in the South of Russia: a collective monograph, 2018: 375). The scientific literature also emphasizes that, despite all the complexities of developing civic patriotism in the youth environment, it is an important factor in the consolidation of youth in the South of Russia (Shevchenko and Vagina, 2017).

Thus, some aspects, related to the study of civic patriotism in regional communities in the South of Russia, have already been considered in the scientific literature. However civic patriotism among young people in the South of Russia as an integral social phenomenon has not yet been the matter of sociological analysis and diagnosis.

\section{METHODOLOGY}

\section{Methodology and sources of empirical information}

The methodological difficulties faced by researchers, studying civic patriotism among young people in the South of Russia, will consist in the fact that in modern scientific discourse there are differing perceptions of what constitutes civic patriotism in Russian society. Thus, some researchers believe that civic patriotism is a system of values that determine the attitude of a person to the society, as well as the attitude of the state to a citizen (Civic patriotism is the basis of the popular majority, 2017). Other researchers emphasize that civic patriotism as love for the motherland, loyalty to Russian traditions and values is interrelated with an active life position, civic responsibility, as well as the formation of civic political culture (Kolesnikov, 2013).

Foreign literature distinguishes "blind" patriotism as an "attachment to the country with unquestioning positive assessment of the homeland and intolerance to criticism of their state" and "constructive" patriotism, expressed in a critical assessment of the state by obtaining information from different sources and the desire to change the situation in the country for the better (Schatz, Staub and Lavine, 1999). In Russian research practices the equivalent of "blind" patriotism is state patriotism, and the equivalent of "constructive" patriotism - civil patriotism (Kolesnikova and Lubsky, 2018).

State patriotism, related with the normative type of national pride, being the result of people's exposure to indoctrination, is characterized by their attachment to the Homeland, unquestioning positive assessment of it, as well as intolerance to criticism of their state. Civic patriotism, associated with a rational type of national pride, involves the willingness of people who are aware of organic belonging to their Homeland, to active and responsible social actions for the good of the motherland, along with their desire to make personal contribution to the development of society and change the situation in the country for the better within the critical attitude to social reality (Nguyen et al., 2020b).

The basis of the academic study of civic patriotism among the youth in the South of Russia was a set of sources of empirical information. This included first the results of a sociological study, conducted in the year 2018, using personal survey questionnaire "face-to-face" in five constituent entities of the Russian Federation in the South of Russia (Rostov region, Stavropol Krai, Republic of Adygea, Kabardino-Balkar Republic and 
the Republic of Crimea). The survey allowed to identify how different youth groups understand patriotism, citizenship and civic patriotism as values and basis of social behaviour. Second, was the information obtained with the help of the focus groups method, applied in the University of Economics and Management (Crimea, Simferopol), the Crimean branch of The Russian State University of Justice (Simferopol), the Southern Federal University (Rostov-on-Don). The focus groups method revealed cognitive and emotional-value features of perception and attitude of students to civil patriotism, their civic patriotic self-identification and motivation to participate in civic patriotic practices. In that case, special attention was paid to external and internal factors contributing to or hindering the development of civic patriotism among young people.

The sociological study has employed methods of qualitative operational analysis and theoretical interpretation of empirical data, as well as methods of sociological diagnosis (Volkov and Lubsky, 2017), aimed at the conceptual generalization of the results of empirical research through social recognition of the qualitative characteristics of civic patriotism in the youth environment as a holistic social phenomenon. In this respect, the results of sociological diagnostics can be used as a basis for system-prognostic analysis and scenario-based modelling of the development of civic patriotism among young people in regional communities in the South of Russia.

\section{RESULTS AND DISCUSSION}

The results of the focus group studies led to conclusion that the civic consciousness of students has a hybrid character, containing elements of both state and civil patriotism. In such consciousness emotional and sensual attitudes associated with love for the motherland and the need to protect it are combined with such rational and pragmatic values as personal dignity, social order, security of the citizen, the integrity of the country. Nevertheless, the results of studies prove that one group of students (the most numerous) is more inclined to state patriotism, the second - to civil, and the third group (the smallest) associates itself with "citizens of the world" and seeks out cosmopolitan type of behaviour. The results of the focus group studies are quite correlated with the results of the questionnaire survey, indicating that among the youth in the regional communities in the South of Russia the statist ideas of patriotism, organically associated with the concept of the motherland and its heroic past, prevail. Therefore, the patriotic attitudes of young people, which are usually mobilization, heroic in nature, receive a real conversion in the social practices of patriotic clubs, organizations and movements of military-patriotic orientation. The growing participation of young people in military-patriotic events and actions, focused mostly on the preservation of military-historical memory and the cultivation of the heroic past of Russia is testimony to this fact. At the same time, the results of focus group studies indicate that a certain part of students, including adherents of state patriotism, are more critical regarding the policy of patriotism among the youth. In so doing, students believe that, on the one hand, patriotism is often "imposed on them by the state", and much in this regard in educational institutions "is done for show", "for the record", for the sake of "some formal reporting". On the other hand, students believe that some participants of youth organizations, "overact in demonstrating their civic position", though they are guided by "career and self-interest motives ". The refrain went through all the focus groups: "Yes, patriotism as a bright idea is great, but when we employ it as cheap populism, use it for selfish purposes, it is disgusting. In fact, it overshadows the idea".

The analysis of the results of the questionnaire survey and focus group studies showed that among the youth there were a lot of those who focus on civic values related to the protection of civil rights and freedoms, critical attitude to social reality and practices of social management, ultimately ready to share responsibility for the fate of the country. It was within young people who noted the civic importance of confronting the arbitrary of the authorities, the importance of active participation in political life, mastering the skills and 
abilities to defend their civil rights and freedoms. In this view, the students pointed out that over the past few years there have been changes in the society regarding the growth of volunteerism and civic activity of young people aimed at providing social assistance to those who need it.

The results of sociological research revealed that youngsters are aware of the presence of public organizations in their regional communities. However, they do not show much interest in participating in the activities of these organizations, though occasionally take part in civic initiatives at the local level, in particular, in activities aimed at improving the public spaces, providing assistance to veterans, low-income families and children. All this testifies to the low level of civic activity in the youth environment related with the active participation of young people in the social life of their settlement. Some respondents observe in the course of focus group studies the low level of their own civil activity, explaining this, first, by the lack of faith in the effectiveness of civil actions. At the same time, they believe that "it's not that people are too lazy to show civic activity, or they are not interested in it, they just understand that it is useless." Besides, they believe "there is no wish to be taken to the police after going to the rally. This will be detrimental to your biography, and therefore it is easier to do nothing". In the course of the focus group studies the students also highlighted that the civic activity of young people is sometimes seeking fashion trends, the desire for "hype" and a new way to promote oneself in social networks rather than the desire to change something in society. "Fashion today, - as the respondents note, - becomes a means of shaping the younger generation." Thus, if it is not possible to develop civic patriotism, based on the values of society, maybe we should use social networks for these purposes, "promoting the values of civic patriotism through fashion." Statements and assessments of students in the course of focus group studies also indicate a low level of self-organization of the youth, their inertia in addressing issues of local importance, social problems of their local communities. Therefore, according to some students, "there are social networks on the Internet, some groups or public pages you can subscribe to and start a discussion about his or her civil and patriotic issues. There are thematic websites. Yes, of course, they are scattered, but they do exist".

In general terms, it should be stressed that the results of sociological research verify weak, fragmentary relationship between semantic and value connotations of patriotism and citizenship in the mass consciousness of young people. Civic attitudes, although they have a certain potential in the youth environment, are not yet in great social demand. Moreover, in the mass consciousness of the youth civic aspirations are not correlated with the idea of patriotism, and therefore patriotism and citizenship are not particularly related to each other. The young people, who can be considered to be the "group of civil patriotism", believe that a patriot should not only love the motherland, but strive to change the situation in the country in order to ensure a decent future for it. According to the results of focus group studies, a certain part of the student youth, critically assessing the situation in the country and critically treating themselves, believes that "patriotism should not be manifested and spoken about every day", "patriotism is a willingness to do something and be responsible for what you do". However, as noted by the respondents, " in the minds of people there is not yet this sense of readiness and responsibility for their actions. Of course, the state is to blame for this, but the people are also to blame. If people wanted to change something, they would do it. They probably don't want to; they are happy with all this".

As the students see the society, "there are still very few people who would be true patriots. For some, patriotism manifests itself, for example, in posting photos on the background of the flag of Russia with the inscription "I am a patriot"." In this regard, respondents emphasize that "patriotism is not just determined by going to a rally, or to the Victory parade, or going along with "The Immortal Regiment". Patriotism lies in performing their duties well. "Therefore, patriotism is" a victory not only in the Great Patriotic War, but also a victory in some actions and in tackling social problems". "Patriotism is first of all an active position aimed at 
improving everyone's life in the state", "patriotism is just when I walk down the street and see someone needing help, I help them, and that what's love for the motherland about!".

Thus, in the youth environment there is a request for civil patriotism and for joint civic patriotic practices. However, the young people believe that "civil patriotism is unconditionally needed. And its need now is extremely high. Because without one we cannot build a civil society." At the same time, they emphasize: "When people, not the state, arrange something by themselves, you feel that you can really handle something and change something. You get motivated, inspired to do something." It should also be noted that in the regional communities in the South of Russia, youth groups have recently appeared, who are putting civic patriotic practices aimed at tackling social problems of local communities first. Nonetheless, the results of sociological studies reveal a low level of civic patriotism among young people. The youngsters explain this by the fact that civic patriotic initiatives are not always supported by the state, which "continues to fuel paramilitary patriotism." As some respondents believe "one gets an impression, that Russia does not really need civil patriotism." The low level of civic patriotism among young people in regional communities in the South of Russia is primarily due to the fragmentary development of civil society institutions in the country, as well as the lack of aspects designed to organize civic patriotic activity and develop civic patriotic responsibility of the youth.

In this regard, the students point out that in Russian society it is necessary to "develop civil patriotism", and we will come to "civil patriotism" provided the state initiates stimulating its development, and "we will not see the worthlessness of our actions." The students emphasize "after all, among our population there are many people who are ready to do something, but they do not see the point in it." Therefore, Russia "needs a more developed civil society, and people should see a feedback to their actions." However, in today Russian society, according to the respondents, "people do not express their civic position, because at some emotional or intuitive level they understand that their actions will be useless, and they will not see a response from the state." "If a person is doing something, but cannot see the output, he or she feels discouraged to go on." The same thing happens when people go to rallies or protests, and then they start having problems with the law. People understand that their actions fail to yield the desired, but cause problems in life, and they will not further seek to change anything.

Sociological research revealed the low level of civic and patriotic activity of young people in the regional communities in the South of Russia. It is also due to insufficient social capital, arising from underdevelopment of civic competence of young people, limited social ties that are necessary for civic participation in certain areas of public life. The lack of social capital in the youth environment is also largely due to the situation in the Russian education system, which today is focused rather on training specialists able to function in a market environment, than on specialists with a high level of citizenship. Therefore, the development of spiritual qualities and related skills of civic patriotism within the youth, as well as their inclusion in active forms of civic and solidarity activities remain on the periphery of the educational space of today Russia.

The focus group research allowed to identify the factors that prevent, according to some students, the development of civic patriotism in the youth environment. One of these factors is inadequate youth policy in educational institutions, associated with the organization of many imitative forms of civic patriotic practices. Another factor, indicated by respondents, hindering the development of civic patriotism, is legal illiteracy of young people, weak legal awareness of legitimate means of protection their social interests and civil rights. One of the factors hindering the formation of civic patriotism in the youth environment is the lack of necessary trust in the state and municipal authorities and, as a whole, negative attitude to their activities, which is 
permeated, according to students, by "bad faith, indifference, greed and corruption." The students emphasize that "our bureaucracy prevents the formation of civic patriotism and civic consciousness".

\section{CONCLUSION}

The carried out sociological research proves, that in the mass consciousness of the youth in the South of Russia civic aspirations do not always correlate with the idea of patriotism, and therefore, patriotism and citizenship are not particularly interlinked in youngsters' minds. In the youth environment, ideas, values and attitudes, inherent in state patriotism, predominate. Such kind of patriotism, which emphasizes love for the motherland and gives young people a feeling of a great country's citizens, is lacking citizenship, which implies the desire to actively participate in the social affairs of society. Therefore, today in regional societies there is a high shortage of grass-roots civic activities for the benefit of society and social environment.

At the same time, in the youth environment, in the South of Russia, the level of civic patriotic consciousness of the youth is gradually growing. Civic patriotic practices are continually encompassing activists, contributing to the solution of social problems in regional communities. However, it should be noted that the civic patriotic activity of youngsters sometimes represents a fashion trend, simulating civic patriotism, rather than a true desire to change something in society.

The sociological diagnostics reveals, on the one hand, a high demand for civil patriotism and joint civic patriotic practices in the youth environment in regional communities in the South of Russia. But on the other hand, the civic and patriotic activity of young people, involving them in volunteer movement and social activities, aimed at improving public spaces and providing social assistance, is still at a low level. This can be explained, firstly, by the fragmentary development of civil society institutions in Russia; secondly, by the lack of aspects in the state youth policy, designed to organize civic patriotic activities and develop civic patriotic responsibility of young people; and thirdly, by the fact that civic patriotic initiatives of young people, as they themselves believe, are not always supported by the state and municipal authorities.

The results of the sociological analysis and diagnostics allowed to point out several factors that prevent the development of civic patriotism among young people in regional communities in the South of Russia. First, it is the youth policy in educational institutions, pursuing various kinds of civil and patriotic practices of an imitative nature. Secondly, it is the low level of self-organization of young people and their civic inertia in tackling social problems within local communities. Third, it is the legal illiteracy of young people and weak legal awareness of legitimate means of defending their social interests and civil rights. Fourth, it is the lack of necessary trust in the state and municipal authorities, as well as negative attitude to their activities, permeated by indifference, bad faith, greed and corruption. Fifth, these are all kinds of bureaucratic constraints imposed on the ground.

\section{ACKNOWLEDGEMENTS}

The article was completed as part of the implementation of the State Assignment (Ministry of Education and Science of the Russian Federation), project No. 28.3486.2017 / PC "Civil patriotism in the formation and development of solidarity practices in the south of Russia: resource potential and conditions for its implementation". 


\section{REFERENCES}

Baibarin, A.A., Mashkin, N.A., and Shelengovskiy, P.G. (2016). The northwest Caucasus from ancient times to the 19th century: a historiographical review of the recent publications in the periodicals. Rusin, 46(4), 119-140. https://doi.org/10.17223/18572685/46/8

Cherdymova, E.I., Afanasjeva, S.A., Parkhomenko, A.G., Ponyavina, M.B., Yulova, E.S., Nesmeianova, I.A., and Skutelnik, O.A. (2018). Student ecological consciousness as determining component of ecological-oriented activity. EurAsian Journal of BioSciences, 12(2), 167-174.

Civic patriotism is the basis of the popular majority. (2017). In Russian. Retrieved from http://valyanko.livejournal.com/595.html

Cohen, J., and Nussbaum, M.C. (1996). For Love of Country: Debating the Limits of Patriotism. Boston: Beacon Press.

Cornilov, G.A., Ilkevich, K.B., Shalomova, E.V., Kartushina, I.G., Musharatsky, M.L., Mashkin, N.A., and Altukhov, S.A. (2019). Features of alcohol consumption motives and practices by full-time and parttime training students. Journal of Environmental Treatment Techniques, 7(3), 438-444.

Faleeva, L.V., Bratukhina, E.V., Ezhov, S.G., Gorbunova, L.N., Lopanova, A.P., Viaznikova, L.F., and Kryukova, N.I. (2017). Student's social experience forming in university vocational training. Eurasian Journal of Analytical Chemistry, 12(7), 1127-1135. https://doi.org/10.12973/ejac.2017.00238a

Gorbunov, M.A., Fadeeva, A.V., Shirshikov, V.B., Matveev, P.A., Popova, O.V., Mitrofanova, M.Yu., Bakaeva, J.Yu., and Mashkin, N.A. (2019). Nature protection potential of wildlife sanctuary: Protection and preservation of its ecological biodiversity. Ekoloji, 107, 5033-5037.

Gorshkov, M.K. (2016). Russian society as it is: (experience of sociological diagnostics). Moscow: New Chronograph.

Koichuev, A.A. (2011). To the problem of the study of citizenship and patriotism of Muslim youth in the North Caucasus. Islamic Studies, 1, 39-46.

Kolesnikov, V.A. (2013). Civil patriotism and civil political culture in modern Russia. Historical, philosophical, political and legal sciences, culturology and art criticism. Questions of theory and practice, 3(29), 84-91.

Kolesnikova, E.Y., and Lubsky, A.V. (2018). Patriotism and citizenship in the youth environment in the South of Russia. Paradigms of sociological research, 7(5), 174-183.

Lubsky, A.V. (2017). Civil patriotism: on the compatibility of patriotism and citizenship in Russian society. Humanities of the South of Russia, 1, 42-59.

Lubsky, A.V. (2019). Patriotism and citizenship in Russian society, or how to overcome the deficit of citizenship in Russian patriotism. Humanities of the South of Russia, 2, 47-66.

Lubsky, A.V., Volkov, Y.G., Vereshchagina, A.V., Kolesnikova, E.Y., and Aslanov, Y.A. (2018). Organizational and Legal Aspects of Patriotic Practices in Regional Communities at the South of Russia. International Journal of Civil Engineering and Technology, 9(11), 180-189.

Makarova, E.V., Kryukova, N.I., Sizova, Z.M., Grinenko, A.V., Erofeeva, M.A., and Bukalerova, L.A. (2019). Divergence of supreme values of Russian world and western civilization social and philosophical analysis. European Journal of Science and Theology, 15(3), 97-107.

Minakhmetova, A.Z., Skutelnik, O.A., Fedorchuk, Y.M., Shulga, T.I., Pavlushin, A.A., and Shagiev, B.V. (2017). Motivational and valuable orientation of teachers as a condition to form students' tolerant behavior. Man in India, 97(3), 323-332.

Mukhametzyanova, L.Y., Aleksandrova, N.S.,Greek, A.D., Zatsepina, M.B., Prokopyev, A.I., and Gaidamashko, I.V. (2018). Culture-oriented component scientific and methodical support of students' humanitarian training in university. XLinguae, 11(1), 230-241. https://doi.org/10.18355/XL.2018.11.01.19 
Nguyen Q.H., Valcova K., Zakirova V.G., Larionova A.A., Lapidus N.I. (2020a). Western science, religion and Vietnamese traditional culture: harmony or antagonism? XLinguae, 13(3), 94-113. https://doi.org/10.18355/XL.2020.13.03.09

Nguyen V.H., Slivka D., Telegina N.V., Zaitseva N.A., Sizova Zh.M. (2020b). Conception of intuition: From the Western philosophy, science, and religion to traditional Vietnamese philosophical thought. XLinguae, 13(3), 216-227. https://doi.org/10.18355/XL.2020.13.03.18

Oborsky, A.Y., Chistyakov, A.A., Prokopyev, A.I., Nikolyukin, S.V., Chistyakov, K.A., and Tararina, L.I. (2018). The national mentality in the history of philosophy. XLinguae, 11(3), 158-165.

Podymov, N.A., Nikoghosyan, M.A., Stolyarova, A.N., Narutto, S.V., Mashkin, N.A., Martynenko, S.E., Paznikova, Z.I., and Varenik, P.K. (2019). University New Educational Reality in Disruptive Technologies Context. Journal of Environmental Treatment Techniques, 7(4), 664-668.

Puzanova, Z.V., and Larina, T.I. (2017). Patriotic education of youth in Russia: problems, opinions, expert assessments. Bulletin of RUDN University. Series: Political Science, 19(1), 25-37. https://doi.org/10.22363/2313-1438-2017-19-1-25-37

Schatz, R.T., Staub, E., and Lavine, H. (1999). On the Varieties of National Attachment: Blind versus Constructive Patriotism. Political Psychology, 20(1), 151-174. https://doi.org/10.1111/0162895X.00140

Semenov, V.E. (2017). Russian identity and patriotism in a polimental society. Social and economic psychology, 2(2), 116-143.

Shakhbanova, M.M. (2017). Patriotism: specificity of formation and functioning in the Republic of Dagestan. Successes of modern science and education, 1(1), 205-208.

Shevchenko, O.M., Vagina, V.O. (2017). Civil patriotism as an idea of consolidation of youth in the South of Russia: specifics and difficulties of formation. Humanities of the South of Russia, 3, 300-309.

Vereshchagina, A.V. (2018). Why patriotism in the South of Russia lacks citizenship (according to the results of a sociological study)? Historical and socio-educational thought, 10(2), 54-64. https://doi.org/10.17748/2075-9908-2018-10-5/2-54-64

Viroli, M. (1997). For Love of Country: An Essay on Patriotism and Nationalism. Oxford: Oxford University Press. https://doi.org/10.1093/0198293585.001.0001

Volkov Y.G., Lubsky, A.V., Kovalev, V.V., Shevchenko, O.M. (2018). Civil organizations and civil institutional practices in the regional communities in the South of Russia. Revista Publicando, 18(2), 115-124.

Volkov, Y.G., Lubsky, A.V. (2017). Sociology in Russia: in search of new ideas and creativity. Rostovon-Don: SFU Publishing house.

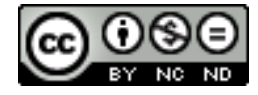

This work is licensed under a Attribution-NonCommercial-NoDerivatives 4.0 International (CC BY-NC-ND 4.0). 